ROBERT E. HALL

Massachusetts Institute of Technology

RICHARD A. KASTEN

Massachusetts Institute of Technology

\title{
The Relative \\ Occupational Success of Blacks and Whites
}

WITHIN THE LABOR MARKET, blacks suffer relative to whites in two ways: first, blacks are less likely to have high-paying occupations than whites, and, second, within each occupation, they are paid less. In this paper, we present and discuss some results of a study of an extensive body of data that has recently become available on the employment histories of young men, both black and white. We hope to contribute some new information from an independent source to the discussion and controversy that has emerged from Richard Freeman's paper in early $1973 .{ }^{1}$

Our first step is to divide the total deficit in black earnings into components attributable to the occupational and wage dimensions. We find that they are approximately equal in size. We go on to study the occupational component in detail, attempting to subdivide it into two parts: differences arising from the unequal treatment of blacks and whites in the labor market and differences arising from the unequal endowments of the two groups. ${ }^{2}$

Note: We are grateful to the National Science Foundation for research support.

1. Richard B. Freeman, "Changes in the Labor Market for Black Americans, 194872," Brookings Papers on Economic Activity (1:1973), pp. 67-120.

2. James S. Coleman, Zahava D. Blum, and Aage B. Sørensen make a similar distinction between the levels of "background resources" and the "efficacy" of the resources 
In comparing men who entered the labor market in the late sixties to those who entered in the early sixties, we find a substantial improvement over the period in the distribution of blacks among occupations. In 1969, 20-year-old blacks had achieved approximately equal occupational success relative to whites, provided account is taken of the disadvantages suffered by blacks because of past discrimination. However, a surprising and disturbing finding of our study is that no progress was made over the same period in reducing the gap between the endowments that blacks and whites brought to the labor market.

\section{Defining Occupations and Measuring Earnings within Occupations}

Our first step is to separate the difference between the average earnings of blacks and whites into two components, corresponding to differences in the distributions among occupations and differences in earnings within occupations. Within our data, occupation is reported as the Census Bureau's three-digit occupational code, which takes on about 500 different values (some occupations are further subdivided by industry of employment). The problem at this point is to group these occupations into a manageable number of categories, since very few of the three-digit occupations have more than ten representatives in our sample, and many have none at all. We took independent data from the 1960 Census of Population on the average earnings in 1959 of all full-year male workers in each detailed occupation, and grouped the occupations into five categories:

\begin{tabular}{|c|c|c|}
\hline Category & $\begin{array}{l}1959 \text { income range } \\
\text { (dollars) }\end{array}$ & Typical occupations in the category \\
\hline 1 & 3,700 or less & $\begin{array}{l}\text { Janitor, automobile service attendant, } \\
\text { kitchen worker }\end{array}$ \\
\hline 2 & $3,701-4,600$ & $\begin{array}{l}\text { Shipping clerk, packer or wrapper, } \\
\text { cook }\end{array}$ \\
\hline 3 & $4,601-5,100$ & $\begin{array}{l}\text { Automobile mechanic, truck driver, } \\
\text { warehouseman }\end{array}$ \\
\hline 4 & $5,101-5,900$ & $\begin{array}{l}\text { Machinist, automobile worker, } \\
\text { carpenter }\end{array}$ \\
\hline 5 & Over 5,900 & School teacher, salesman, plumber \\
\hline
\end{tabular}

in the labor market ("Occupational Status Changes for Blacks and Nonblacks During the First Ten Years of Occupational Experience," Report 76, Johns Hopkins University, Center for Study of Social Organization of Schools, August 1970, revised October 1971; processed). Their data refer to the cohort born between 1929 and 1938, so their results do not bear directly on Freeman's hypothesis. 
Table 1. Average Wage Rates for Black and White Males, and Distribution by Occupational Category, Selected Age Groups, 1969

\begin{tabular}{|c|c|c|c|c|c|c|}
\hline \multirow[b]{2}{*}{ Race } & \multicolumn{6}{|c|}{ Occupational category } \\
\hline & $\begin{array}{l}\text { All cate- } \\
\text { gories }\end{array}$ & $\begin{array}{c}1 \\
\text { (worst) }\end{array}$ & 2 & 3 & 4 & $\begin{array}{c}5 \\
\text { (best) }\end{array}$ \\
\hline Wage (dollars per hour) & \multicolumn{6}{|c|}{ Aged 23 to 27} \\
\hline Black & 2.55 & 1.61 & 2.42 & 2.58 & 3.27 & 3.46 \\
\hline White & 3.68 & 2.35 & 3.16 & 3.26 & 3.68 & 4.18 \\
\hline Ratio & 69 & 69 & 77 & 79 & 89 & 83 \\
\hline \multicolumn{7}{|l|}{ Percent in category ${ }^{b}$} \\
\hline Black & 100 & 21 & 27 & 24 & 19 & 8 \\
\hline White & 100 & 5 & 10 & 19 & 27 & 39 \\
\hline Wage (dollars per hour) & \multicolumn{6}{|c|}{ Aged 17 to 22} \\
\hline Black & 2.30 & 1.68 & 2.24 & 2.41 & 3.05 & 2.85 \\
\hline White & 2.74 & 2.00 & 2.70 & 2.63 & 3.03 & 3.11 \\
\hline Ratio & 84 & 84 & 83 & 92 & 101 & 92 \\
\hline \multicolumn{7}{|l|}{ Percent in category ${ }^{\mathrm{b}}$} \\
\hline Black & 100 & 24 & 34 & 20 & 16 & 6 \\
\hline White & 100 & 13 & 23 & 22 & 24 & 17 \\
\hline
\end{tabular}

Source: National Longitudinal Survey, conducted by the U.S. Bureau of the Census periodically since 1966.

a. The occupational categories are based on annual income ranking, using average earnings in 1959 of all full-year male workers holding jobs under the detailed occupational classifications reported in U.S. Bureau of the Census, U.S. Census of Population, 1960, Occupational Characteristics, Final Report PC (2)-7A (1963). Occupations with 1959 incomes of $\$ 3,700$ or less are in category $1 ; \$ 3,701-\$ 4,600$, category 2 ; $\$ 4,601-\$ 5,100$, category $3 ; \$ 5,101$ to $\$ 5,900$, category 4 ; and over $\$ 5,900$, category 5 .

b. Percentages may not add exactly to 100 because of rounding.

Every employed man in our sample can then be assigned to one of the five categories on the basis of the occupation he reports. Although the definition of the categories depends on the earnings of individuals holding the occupations, we emphasize that the occupational category into which we put a member of our sample does not depend on his actual earnings, nor on any other of his characteristics, including his race.

Table 1 presents wage rates for black and white males in two age groups, 23 to 27 and 17 to 22, for November 1969. The data for this table and for all of the results presented in the rest of this paper were obtained from the National Longitudinal Survey of Work Experience, carried out by the Bureau of the Census under the direction of Herbert S. Parnes of Ohio State University. ${ }^{3}$ In the older group, the average black earns 31 percent less per hour than does the average white- $\$ 2.55$ against $\$ 3.68$. Holding

3. For a description of the survey, see David N. Saunders, "Labor Force Behavior: A Longitudinal Perspective," Review of Public Data Use, Vol. 1 (July 1973), pp. 7-13. 
occupation constant, we find that black males earn from 69 percent to 89 percent as much as whites in the same occupation. To measure the average deficit in the wages of blacks, we pose the following question: How would average black wages compare with average white wages if there were no difference in the distribution of blacks and whites among occupations? If black males earned the wages shown in the top line of Table 1 but were distributed among the occupations according to the distribution for whites shown on the fifth line, their average wage would be $\$ 3.05,17$ percent below the average for whites. The remaining 14 percent of the total deficit of 31 percent can be attributed to the adverse occupational distribution for blacks.

In the younger group, the situation is somewhat more favorable. The average black wage of $\$ 2.30$ is only 16 percent lower than the average for whites of $\$ 2.74$. Of this, 9 percent is attributable to lower wages within occupations and 7 percent to the adverse distribution of blacks among occupations.

In both groups, the wages of black males come closest to those of white males in the fourth occupational category. These jobs are typically highpaying blue-collar jobs, requiring substantial skill but not much formal education. The largest gap appears in the lowest occupational category. Not only is there an excessive number of blacks holding the poorest jobs, but those are precisely the jobs in which blacks suffer the most relative to whites.

\section{Occupational Success}

In this paper we focus on the occupational dimension of differences between black males and white males. As was shown in the preceding section, this dimension accounts for nearly half of the total difference in wage rates. In our study of the relative occupational success of blacks and whites, we make use of a fairly elaborate model of the activities of young men aged 14 to 26 that we have developed recently. Because of lack of data on earnings of many of the jobs held by the members of our sample, our model deals with occupational status but not directly with earnings, so we will have nothing further to say about the second dimension of blackwhite differences in earnings.

The model, which will be described in detail in a future paper, takes ac- 
count of the way an individual's probability of occupational success depends on his personal characteristics or endowments. Thus the model makes it possible to estimate the fraction of the deficit in black occupational success attributable to the unequal treatment of black men in the labor market and the fraction arising from their inadequate endowments, which in turn is the result of past discrimination. We find that there is a sense in which Freeman's optimistic view is entirely correct: by the end of the sixties, a black could expect the same success in the labor market as a white with the same endowment. We have three measures of an individual's endowment: family background as indicated by his father's occupation, the highest grade he has completed in school, and his achievement in school as measured by tests. Holding these constant, we find that young black men entering the labor market in the late sixties were just as likely as whites to find high-paying jobs and just as likely to escape from bad jobs. On the other hand, blacks suffer considerably from adverse endowments. Past discrimination has a lingering effect through its influence on family background. The inadequacy of the schools attended by blacks causes them to complete fewer grades and to score substantially lower on achievement or other tests. Thus a black drawn at random from the population of young men will tend to have lower values of all three of our endowment variables than will a white, and this in turn implies that the black will have a lower probability of success in the labor market.

\section{The Model}

Our model deals with the probabilities of leaving and returning to school, finding the first job, losing or leaving jobs, promotion, advancement through changing jobs, and marriage and divorce. Within the model, occupational status is measured by the categories defined at the beginning of the paper. Unlike the well-known measure of the socioeconomic status of occupations developed by Otis Dudley Duncan, our set of categories considers only the income of the occupations, not their prestige or other nonmonetary returns. We do, however, use Duncan's socioeconomic status (SES) scores as an index of the father's occupation in quantifying family background. 4

4. Otis Duncan Dudley and others, Socioeconomic Background and Achievement (Seminar Press, 1972). 
Three of the equations in our model are particularly important for our purposes. These are (1) the "first job" equation, which assigns the individual to one of the five categories at the time he leaves school and begins full-time work; (2) the "new job" equation, which gives the category of his new job if he changes jobs; and (3) the "promotion" equation, which determines each year whether he moves up to a better category with the same employer. The right-hand variables in all of these equations include the socioeconomic status of the father's occupation, the highest grade of school completed by the individual (not his years of school-many members of the sample have flunked at least once), his test score (converted to a uniform measure with mean 100), his age, and dummy variables for the year. The new job and promotion equations also depend on the category and on the length of time on the previous job. There are completely separate equations for blacks and whites.

\section{AN INDEX OF OCCUPATIONAL SUCCESS}

Our model predicts the probability that an individual will hold a job in each of the five categories. These five probabilities sum to 100 percent and depend on the characteristics of the individual. In most cases we will present the complete distribution among the five categories, but we also need a summary index of the distribution. For this purpose we define expected earnings as the earnings the individual would expect to receive (in the statistical sense) if he were paid the following in each category:

$\begin{array}{cc}\text { Category } & \begin{array}{c}\text { Hourly wage } \\ \text { (dollars) }\end{array} \\ 1 & 2.51 \\ 2 & 3.16 \\ 3 & 3.69 \\ 4 & 4.18 \\ 5 & 4.79\end{array}$

These wages were obtained by taking the midpoints of the earnings ranges used to define the categories and then adjusting them proportionately to make the wage in category 2 equal the wage for white males aged 23 to 27 reported in Table 1. In category 1 the result is close to the wage for whites in Table 1. For categories 3, 4, and 5, however, the averages for whites in our sample are well below the values that we use in our index (see Table 1). 
The two lowest categories contain secondary jobs with high turnover and almost no return to seniority; hence our sample of young workers earns about the same as the older workers in the Census data that we used to calculate earnings by detailed occupations. Categories 3,4 , and 5 are primary jobs, where young workers are paid substantially less than older workers. We believe that it is more appropriate to use the Census wages rather than the averages for the young workers in our sample, in order to take rough account of the superior value of primary jobs. ${ }^{5}$

To convert the expected wage to an index, we simply divide by $\$ 3.69$, the wage the individual would receive if he were certain of a job in category 3. This gives our index of occupational success (IOS), which can be restated as

$$
I O S=\frac{2.51 N_{1}+3.16 N_{2}+3.69 N_{3}+4.18 N_{4}+4.79 N_{5}}{3.69} .
$$

Here $N_{1}, \ldots, N_{5}$ are the probabilities assigned to the five categories, expressed as percentages. We also define the index of relative occupational success (IROS) as the ratio of the black IOS to the white IOS. The IROS measures only the part of the difference in the earnings of blacks and whites that can be attributed to the adverse distribution of blacks among occupations, and says nothing about the disadvantage of blacks within each occupation.

\section{Comparison of Blacks and Whites with Equal Endowments}

In this and the next section, we compare the experiences of black men and white men in two cohorts-those born in 1943 and those born in 1949. These are the earliest and latest cohorts for which our model is likely to give reliable results. First we look at the question of the relative occupational success of blacks and whites with equal endowments by posing the following questions: What happened to 100 blacks whose fathers' SESs

5. Readers familiar with the literature on human capital and learning on the job may find the argument more convincing if it is phrased in the following way: For young men, jobs in categories 3,4 , and 5 involve substantial investment on the job, while those in categories 1 and 2 do not. The gross return to a job is the sum of its pay and the value of the training it provides. We approximate the relative gross return of our categories by using data on earnings for older workers, who presumably learn much less on the job in all categories. 
Table 2. Occupational Distribution and Success Indexes, Male Workers with Equal Endowments, by Race, First Jobs, 1961 and $1967^{\mathrm{a}}$

Distribution in percent

\begin{tabular}{|c|c|c|c|c|c|c|c|}
\hline \multirow[b]{2}{*}{ Age group and race } & \multicolumn{5}{|c|}{ Occupational category $y^{\mathrm{b}}$} & \multirow{2}{*}{$\begin{array}{l}\text { Index of } \\
\text { occupational } \\
\text { success } \\
\text { (wage in } \\
\text { category } 3 \\
=100 \text { ) }\end{array}$} & \multirow{2}{*}{$\begin{array}{l}\text { Index of } \\
\text { relative } \\
\text { occupationa } \\
\text { success } \\
\text { (black-white } \\
\text { equality } \\
=100 \text { ) }\end{array}$} \\
\hline & $\begin{array}{c}1 \\
\text { (worst) }\end{array}$ & 2 & 3 & 4 & $\begin{array}{c}5 \\
\text { (best) }\end{array}$ & & \\
\hline \multicolumn{8}{|c|}{ Born 1943, first job 1961} \\
\hline Black & 42 & 28 & 13 & 10 & 7 & 86 & \multirow{2}{*}{95} \\
\hline White & 31 & 23 & 22 & 18 & 16 & 91 & \\
\hline \multicolumn{8}{|c|}{ Born 1949, first job 1967} \\
\hline Black & 19 & 23 & 19 & 34 & 5 & 97 & \multirow{2}{*}{105} \\
\hline White & 31 & 23 & 19 & 19 & 7 & 92 & \\
\hline
\end{tabular}

Source: Authors' model, using data from the National Longitudinal Survey.

a. Based on a sample consisting of four groups of 100 workers each-black, white, born in 1943, and black, white, born in 1949, all with equal endowments as described in the text.

b. See Table 1 , note $a$, for description.

c. Ratio of black index of occupational success to white index of occupational success.

were 36 (the median for whites), who left school and entered the labor market at age 18, having completed high school with an achievement score of 100 ? What happened to 100 whites with the same characteristics? We look at the members of each cohort in two ways: first, as they enter the labor market in 1961 or 1967, and, second, as they find themselves in 1969. In all cases, we are examining the model within the period in which it was estimated-1960-69 for the first job and 1967-69 for new jobs and promotions. At the conclusion of the paper, we discuss extrapolation of the model to 1973 .

Table 2 shows the distribution of the four groups of 100 workers each when they take their first jobs. ${ }^{6}$ Black men entering the labor market in 1961 faced a bleak prospect-42 percent of them took jobs in the very worst category, and 28 percent more were in the second category. Whites did considerably better. Only 54 percent are in the bottom two categories. By our index of relative occupational success, blacks found first jobs that

6. Our model is formulated in terms of probabilities throughout. Thus Table 2 shows the probabilities given by the first-job equation for the individual whose characteristics we have just specified. The probabilities are estimated from a total sample of 1,438 blacks and 3,787 whites. 
Table 3. Occupational Distribution and Success Indexes for Male Workers with Equal Endowments, after Eight and Two Years' Experience, by Race, 1969a

Distribution in percent

\begin{tabular}{|c|c|c|c|c|c|c|c|}
\hline \multirow[b]{2}{*}{ Age group and race } & \multicolumn{5}{|c|}{ Occupational category } & \multirow{2}{*}{$\begin{array}{l}\text { Index of } \\
\text { occupational } \\
\text { success } \\
\text { (wage in } \\
\text { category } 3 \\
=100 \text { ) }\end{array}$} & \multirow{2}{*}{$\begin{array}{l}\text { Index of } \\
\text { relative } \\
\text { occupational } \\
\text { success } \\
\text { (black-white } \\
\text { equality } \\
=100 \text { ) }\end{array}$} \\
\hline & $\begin{array}{c}1 \\
\text { (worst) }\end{array}$ & 2 & 3 & 4 & $\begin{array}{c}5 \\
\text { (best) }\end{array}$ & & \\
\hline \multicolumn{8}{|c|}{ Born 1943, first job 1961} \\
\hline Black & 8 & 24 & 24 & 32 & 13 & 103 & \multirow{2}{*}{94} \\
\hline White & 9 & 9 & 21 & 33 & 28 & 109 & \\
\hline \multicolumn{8}{|c|}{ Born 1949, first job 1967} \\
\hline Black & 11 & 27 & 25 & 25 & 12 & 100 & \multirow{2}{*}{100} \\
\hline White & 16 & 21 & 23 & 23 & 17 & 100 & \\
\hline
\end{tabular}

Source: Same as Table 2.

a. See Table 2, note $a$.

b. See Table 1, note $a$, for description.

c. Ratio of black index of occupational success to white index of occupational success.

were on the average 5 percentage points below those found by whites. In 1967, the situation was just the reverse; blacks entered the labor market 5 points above whites. Only 42 percent of the blacks took jobs in the bottom two categories, while 54 percent of the whites took jobs there, exactly the same fraction as in 1961. Table 2 by itself seems to justify Freeman's diagnosis of "a virtual collapse in traditional discriminatory patterns in the labor market."7 We shall show, however, that the unfavorable endowments of blacks, even those born in 1949, put them in an adverse position relative to whites even in the last year we observed them, 1969. Moreover, there is evidence in our results that the position of blacks relative to whites with equal endowments is less favorable when the comparison is made at lower levels of endowments. We return to this point later in the paper.

Table 3 shows the combined operation of the first-job, new-job, and promotion equations. The cohort of 1943 has moved well up the occupational ladder from its starting position as reported in Table 2. The IOS for black men has risen from 86 to 103 and that for white men from 91 to 109. The IROS remains almost unchanged. The younger cohort of 1949 shows less upward movement since it has been at work for only two years.

7. "Changes in the Labor Market," p. 67. 
Still, the black IOS has risen from 97 to 100 and the white $I O S$ from 92 to 100 . The IROS falls from its level of 105 in 1967 to 100-exact equality between blacks and whites-in 1969. According to our model, then, blacks whose education, school achievement, and family background were at the median level for whites would on the average hold jobs about 6 percent lower in the occupational structure than comparable whites if they entered the labor market early in the sixties, ${ }^{8}$ and would hold equally good jobs as whites if they entered in 1967. Since our model has separate equations for blacks and whites, it is quite possible that comparisons based on it would be rather different if they were made at a lower level of endowments. To check this we recalculated the data in Table 3 for individuals whose fathers' SESs were 16, whose test scores were 90, who left school after the tenth grade, and who entered the labor market in 1965. These values are close to the medians for blacks. For the older cohort, we found that the IOS for black men was 95 compared with 103 in Table 3, and for white men was 103 compared with 109. The IROS is 93 for the lower level of endowments compared with 94 in Table 3. There is some tendency, although it is not marked, for the gap between blacks and whites in this age group to be widest for the most disadvantaged members. The results for the younger cohort are more striking but harder to interpret. The IOS is 93 for blacks and 97 for whites, compared with 100 for both in Table 3 . The IROS is 96 against 100 for the more favorably endowed group. However, these individuals entered the labor market two years earlier, in 1965 rather than 1967, and benefited much less from the spectacular improvement in the quality of the first jobs available to blacks later in the sixties. After allowing for this, we find about the same tendency for the gap to widen for the disadvantaged as we found for the older cohort.

\section{Comparison of Random Groups of Blacks and Whites}

We find much less optimistic results if we take into account the unequal endowments of blacks and whites. Here we pose two questions that parallel those just discussed: What happened to 100 black men chosen at random from the population born in 1943 or 1949 ? What happened to 100 white

8. For reasons that we will discuss shortly, we have probably understated the deficit for the older cohort. 
men chosen at random? Once again, we could look at first jobs, promotions, and changes in jobs, but the distribution in 1969 tells the unhappy story by itself quite well. A black with the average white endowment, born in 1943, would have only a 32 percent probability of holding a job in the bottom two categories but Table 4 shows that a black chosen at random from the population has a 40 percent probability of holding a bad job. For those born in 1949, the situation is even worse: 38 percent would have bad jobs if they had the average endowments of whites, but in fact 57 percent are in the two worst categories. For the older group the IROS is 88, compared with 94 when endowments are held constant. In this cohort, about half of the difference between black and white occupational success in 1969 was caused by the unfavorable treatment of blacks in the labor market (mostly in the early sixties) and half by their unfavorable endowments. For the younger cohort, born in 1949, the IROS is 94 for individuals chosen at random, but all of the shortfall is caused by the inadequate endowments of blacks - the IROS for identical individuals in Table 3 is precisely 100 . The surprising finding is that while the sixties saw the nearly complete elimination of racial bias in the way that the labor mar-

Table 4. Occupational Distribution and Success Indexes for Male Workers Selected at Random, after Eight and Two Years' Experience, by Race, 1969a

Distribution in percent

\begin{tabular}{|c|c|c|c|c|c|c|c|}
\hline \multirow[b]{2}{*}{ Age group and race } & \multicolumn{5}{|c|}{ Occupational category ${ }^{b}$} & \multirow{2}{*}{$\begin{array}{l}\text { Index of } \\
\text { occupational } \\
\text { success } \\
\text { (wage in } \\
\text { category } 3 \\
=100)\end{array}$} & \multirow{2}{*}{$\begin{array}{l}\text { Index of } \\
\text { relative } \\
\text { occupational } \\
\text { success } \\
\text { (black-white } \\
\text { equality } \\
=100 \text { ) }\end{array}$} \\
\hline & $\begin{array}{c}1 \\
\text { (worst) }\end{array}$ & 2 & 3 & 4 & $\begin{array}{c}5 \\
\text { (best) }\end{array}$ & & \\
\hline \multicolumn{8}{|c|}{ Born 1943, first job 1961} \\
\hline Black & 17 & 23 & 22 & 26 & 12 & 98 & \multirow{2}{*}{88} \\
\hline White & 9 & 9 & 19 & 26 & 38 & 112 & \\
\hline \multicolumn{8}{|c|}{ Born 1949, first job 1967} \\
\hline Black & 25 & 32 & 22 & 15 & 7 & 92 & \multirow{2}{*}{94} \\
\hline White & 19 & 22 & 24 & 21 & 14 & 98 & \\
\hline
\end{tabular}

Source: Same as Table 2.

a. Based on a sample consisting of four groups of 100 workers each-black, white, born in 1943, and black, white, born in 1949, chosen at random from the population.

b. See Table 1 , note $a$, for description.

c. Ratio of black index of occupational success to white index of occupational success. 
ket assigned individuals to occupations, literally no progress was made during the period in augmenting the endowments of blacks relative to whites.

Why is the contrast so striking between the successful elimination of occupational discrimination and the complete failure to improve the qualifications of black men relative to white men? We can only offer a few conjectures in answer to this difficult question, and introduce some additional evidence in support of our finding. First, there obviously was little scope for improvement in our measure of family background in the six years separating our cohorts, since it reflects the extreme and stable condition of discrimination in the labor market existing when their fathers established their careers in the 1930s. The average SES of the fathers of our black cohorts rose from 17 to 18 from 1943 to 1949, but the increase for whites was larger, from 35 to 38 , so blacks actually lost ground relative to whites. Not until the sons of our cohorts enter the labor market in the 1990s will the recent improvement in the treatment of young blacks feed back to improve the endowments of blacks in the labor market. There is a fundamental limitation on the speed of operation of a process that depends on transfers from one generation to the next. ${ }^{9}$

Second, the failure of blacks to show any improvement in school achievement relative to whites is more difficult to explain. The desegregation of schools in the South should have had some impact on our younger cohort; and we expected some evidence of the effect of federally supported programs of compensatory education, although most of these were aimed at younger groups. Yet the black test scores of our two cohorts diverge slightly from the white scores: black men born in 1943 scored about 15 percent below white men born in the same year, while blacks born in 1949 scored about 17 percent below their white counterparts. ${ }^{10}$ Apparently edu-

9. The preliminary results of work done by Kasten on the data on mature men collected by Parnes indicate that it will not be necessary to wait a full generation to find an improvement in the endowments of blacks entering the labor market. A substantial improvement seems to have taken place in the relative occupational success of blacks over 45 at the end of the 1960s. If the fathers of teenagers have enjoyed the same improvement as younger and older blacks, an immediate feedback will occur.

10. We should caution the reader that the test scores are by far the weakest part of the data from the National Longitudinal Survey. They are missing for 27 percent of the whites and 58 percent of the blacks, and are calculated by recoding the results of a wide variety of standardized tests. 
cational reform takes too long for its effect to show in comparing cohorts spaced by six years.

Third, the failure to close the educational gap between black and white men is even more surprising, in view of the progress in this direction made before the sixties. It is a remarkable fact that, in the six years separating our cohorts, literally no improvement was recorded in the highest grade completed by blacks relative to whites. According to the 1970 Census, the median grade completed by whites rose from 12.7 to 12.9 between the cohorts of 1943 and 1949, and the median grade for blacks rose by slightly less, from 12.1 to 12.2 . These figures conceal a dramatic difference in schooling completed-for example, the fractions of blacks completing high school were 55 and 58 percent for the two cohorts, against 76 and 81 percent for whites. ${ }^{11}$

By all three of our measures, black men failed to progress relative to white men in the endowments they brought to the labor market, even though there was enormous improvement in the return to those endowments for blacks within the labor market. This strikes us as a major problem for further research. It also suggests caution in making optimistic interpretations of the very significant recent improvement in the relative earnings of blacks.

\section{Comparison with Actual Distributions}

Tables 3 and 4 were calculated from our model and are connected to the underlying data only through the estimated parameters of the model, and, in the case of Table 4, through the actual distribution of endowments within the population. The difference between the two tables is our only measure of the effect of adverse endowments on the relative occupational success of black men, and we have no reason to doubt the validity of the comparison. No sample data exist to compare with Table 3, but data appearing in the lower part of Table 1 can be used for comparison with the results in Table 4. For whites and for the younger blacks, it appears that our model predicts the occupational distribution fairly well: The $I O S$ for older whites in Table 1 is 112, exactly the same as reported in Table 4.

11. U.S. Bureau of the Census, Census of Population, 1970, Final Report PC(2)-5B, Educational Attainment (1973), pp. 36, 41. 
For the younger blacks it is 91 , against 92 in Table 4, and for the younger whites it is 100 against 98 . But for the older blacks, the $I O S$, if calculated from the data in Table 1, is 83 while the model predicts 98 . Apparently this discrepancy is the result of an inescapable deficiency of the model: the promotion equation was estimated during a period of active promotion of blacks (1967 to 1969), but is applied in our work to individuals starting in 1962. Our model overstates the rate of promotion because we were forced to use the parameters for 1967 in calculating the probabilities of promotion in 1962-66.

A more realistic procedure, then, for measuring the total difference between blacks and whites is to use the IROS from the data shown in Table $1-83$ for the older cohort and 91 for the younger. The differences between Tables 3 and 4 measure the amount of the deficit in black occupational success that can be attributed to the adverse endowments of blacks- 6 percent for both cohorts. The remainders, 11 percent for the older cohort and 3 percent for the younger, are probably more reasonable estimates of the effects on occupational distribution of the unequal treatment of equally endowed blacks and whites in the years 1961 through 1969.

\section{Projections to 1973}

What would have happened if the labor market had treated black men in 1970-73 as favorably as it treated them in 1969? This question is answered in Table 5. Holding endowments equal, blacks born in 1943 would be within 2 percentage points of equality in occupational success with whites and the younger cohort would remain at almost exact equality. The model predicts no tendency for black earnings to fall with age relative to white earnings, thus confirming one of Freeman's main arguments. In our model, the tendency for older blacks to earn less relative to whites than do younger blacks in the same year is explained by the more favorable treatment of the younger cohort, not by a flatter age-income profile for blacks. A similar convergence to a level about 7 percent below the white level appears when differences in endowments are taken into account. Our model predicts that this difference will persist throughout the careers of both cohorts. Only the long-run process of improvement in the relative endowments of blacks can eliminate the remaining deficit for future cohorts. 
Table 5. Projections to 1973 of Occupational Distribution and Success Indexes for Male Workers after Twelve and Six Years' Experience, by Race Distribution in percent

\begin{tabular}{|c|c|c|c|c|c|c|c|}
\hline \multirow[b]{2}{*}{ Age group and race } & \multicolumn{5}{|c|}{ Occupational category } & \multirow{2}{*}{$\begin{array}{l}\text { Index of } \\
\text { occupational } \\
\text { success } \\
\text { (wage in } \\
\text { category } 3 \\
=100)\end{array}$} & \multirow{2}{*}{$\begin{array}{l}\text { Index of } \\
\text { relative } \\
\text { occupational } \\
\text { success } \\
\text { (black-white } \\
\text { equality } \\
=100)\end{array}$} \\
\hline & $\begin{array}{c}1 \\
\text { (worst) }\end{array}$ & 2 & 3 & 4 & $\begin{array}{c}5 \\
\text { (best) }\end{array}$ & & \\
\hline \multicolumn{8}{|c|}{ Workers with equal endowments } \\
\hline Born 1943, first job I & & & & & & & \multirow{3}{*}{98} \\
\hline Black & 9 & 17 & 15 & 41 & 18 & 106 & \\
\hline White & 7 & 8 & 25 & 40 & 20 & 108 & \\
\hline \multicolumn{8}{|c|}{ Born 1949, first job 1967} \\
\hline Black & 6 & 20 & 19 & 35 & 20 & 106 & \multirow{2}{*}{101} \\
\hline White & 8 & 14 & 25 & 35 & 18 & 105 & \\
\hline \multicolumn{8}{|c|}{ Workers selected at random } \\
\hline Born 1943, first job 1 & & & & & & & \multirow{3}{*}{91} \\
\hline Black & 19 & 19 & 13 & 32 & 17 & 101 & \\
\hline White & 7 & 7 & 23 & 30 & 33 & 111 & \\
\hline \multicolumn{8}{|c|}{ Born 1949, first job 1967} \\
\hline Black & 17 & 24 & 18 & 26 & 15 & 99 & \multirow{2}{*}{93} \\
\hline White & 8 & 13 & 24 & 27 & 28 & 107 & \\
\hline
\end{tabular}

Source: Projections from authors' model, assuming that blacks received the same favorable treatment in the labor market in 1970-73 that they received in 1969.

a. See Table 1, note $a$, for description.

b. Ratio of black index of occupational success to white index of occupational success.

Until data from the National Longitudinal Survey become available for the years 1970 through 1973, we will not know how unrealistic these projections are. The recession of 1970-71 makes it unlikely that the upward mobility of blacks continued at the high rate of 1968-69, but we have little information about the experience of blacks relative to whites during the period. 


\section{Discussion}

BARRY BOSWORTH SUGGESTED that the heart of the Hall-Kasten paper lay in a statistical taxonomy that split the differential in occupational success of blacks into two: one part was attributed to differences in endowments, and the remainder to discrimination in the labor market. He expressed his concern that some of the statistical effect of the variables designed to measure endowments could in fact reflect the workings of discrimination. For example, the lesser occupational success of a black youth whose father had low socioeconomic status might not reflect solely the lower human capital he brought to the labor market, but might stem also from subtle hiring practices that discriminate against young men from the ghetto. William Nordhaus was similarly unconvinced that the social, family, and education characteristics that the paper identifies as "endowments" are really the criteria by which employers make decisions about hiring and promoting people.

Charles Holt and Edward Gramlich noted that some of the improvement in occupational status between 1961 and 1967 might result from enhanced employment opportunities in a tight labor market rather than from the permanent breakdown of discriminatory barriers. Hall explained that it was impossible to control for changes in labor market tightness since the data were available for only a few periods; but he felt somewhat reassured by Richard Freeman's previous findings that cyclical fluctuations explained only a small portion of black-white occupational differences. He conceded that, because blacks have more unemployment than whites throughout the business cycle, the occupational comparisons reveal only one aspect of the differences between black and white experiences in the labor market.

Holt was extremely interested in the results presented by Hall and Kasten, but he viewed this paper as the tip of an iceberg representing a much larger piece of research. More discussion and fuller testing of the model were needed before a final judgment could be made. He and Robert Solow were concerned that the use of only five occupational categories might miss significant types of discrimination.

Several participants commented on the disadvantageous endowment of 
young blacks. Richard Freeman suggested another dimension of socioeconomic status that might be tried: whether a youth had been brought up in an intact or broken family might affect his economic position in the labor market. In response to a query from Robert J. Gordon, the authors explained that education accounted for more than half of the endowment disadvantage of blacks relative to whites. Although the endowment variables were correlated with one another, the importance of the education variables could be viewed optimistically: greater equality in schooling was more readily and more promptly achievable than changes in family status. Freeman added that the differences in endowments raised important policy issues. What responsibility should the government take for helping blacks in the short run to overcome long-run disadvantages in endowment? To what extent could it also help whites who had poor endowments for the labor market? More generally, what does equality of opportunity mean when endowments are different? 